\title{
WHICH FINISHING AND POLISHING TECHNIQUE IS MORE EFFECTIVE FOR SURFACE ROUGHNESS AND MICROHARDNESS?
}

\begin{abstract}
Purpose: The aim of this study was to evaluate the effects of finishing and polishing $(\mathrm{F} / \mathrm{P})$ techniques on resin restorative materials' surface roughness and microhardness.

Materials and methods: A total of 168 specimens were prepared using compomer, resin composite, and giomer, and subjected to F/P and F/P was performed using Sof-Lex Discs, Sof-Lex Spiral Wheels, and Enamel Plus Shiny. No F/P was performed in the control group. Surface roughness and microhardness were measured. Data were analyzed using one-way ANOVA, two independent samples t-test, and KruskalWallis test. The correlations between parameters was investigated using Pearson's correlation test $(\mathrm{p}<0.05)$.
\end{abstract}

Results: Enamel Plus Shiny and the control group were not significantly different in terms of surface roughness. For Sof-Lex Disc, Dyract XP resulted in a significantly higher surface roughness. For SofLex Spiral Wheels, Filtek ${ }^{\mathrm{TM}}$ Bulk Fill resulted in a statistically significant lower surface roughness $(p<0.05)$. In terms of microhardness, Beautifil II resulted in a significantly higher microhardness in the Sof-Lex Disc group ( $\mathrm{p}<0.05)$. In the control group, Dyract XP resulted in a significantly lower microhardness compared to Filtek $^{\mathrm{TM}}$ Bulk Fill and Beautifil II. Sof-Lex Spiral Wheels and Enamel Plus Shiny had statistically different microhardness results. Surface roughness and microhardness values were positively correlated for Filtek ${ }^{\mathrm{TM}}$ Bulk Fill and negatively correlated for Dyract XP and Beautifil II.

Conclusions: Proper F/P procedures are essential for aesthetics and longevity of restorations. Within the limits of our study, it has been concluded that the effects of the F/P process depend on both the material and technique used for finishing and polishing, and the restorative material.

Keywords: Dental finishing, dental polishing, dentistry, operative, dental materials.
*Elif Gül Aydın ${ }^{1}$

Nurhan Ozalp ${ }^{2}$

ORCID IDs of the authors:

E.G.A. 0000-0002-6034-0029

N.O. $\quad 0000-0003-4192-2960$

1 Department of Pedodontics, Faculty of Dentistry, Sakarya University, Sakarya, Turkey. 2 Department of Pedodontics, Faculty of Dentistry, Ankara University, Ankara, Turkey.
Received : 18.09 .2020

Accepted : 18.12 .2020

How to Cite: Gül Aydın E, Özalp N. Which Finishing and Polishing Technique is More Effective for Surface Roughness and Microhardness? Cumhuriyet Dent J 2021;24:1: 21-29.

*Corresponding Author:

Department of Pedodontics, Faculty of Dentistry, Sakarya University Mithatpaşa mah, Adnan Menderes Cd. No:122/B, 54100 Adapazar1/Sakarya, Turkey. 


\section{INTRODUCTION}

The surface characteristics of resin composite restoratives are defined as one of the most prominent factors determining the clinical success. ${ }^{1-6}$ The presence of surface irregularities can influence appearance, plaque accumulation, surface discoloration, gingival inflammation, discomfort, and treatment outcomes, including mechanical weakness and aesthetic properties. , $6-9^{-9}$

Proper finishing of restorations is desirable not only for aesthetic considerations but also for oral health. ${ }^{1,4-5,8}$ Finishing and polishing are required to improve both surface roughness and microhardness for a successful restoration. ${ }^{4,5,8,10}$

Resin restorative materials are affected by the flexibility of finishing and polishing materials, as well as the hardness and size of the abrasive particles. ${ }^{11-13}$ Abrasive polishing discs are usually produced by covering a polymer or plastic surface with aluminum oxide particles. ${ }^{6,8,13,14}$ Polishing is performed using thick-grained followed by finergrained discs. ${ }^{2,8}$ Abrasive-impregnated polishing brushes are available in different shapes (pointed, wheel-shaped, cup-shaped) and with polymer strings, so that they can effectively reach fissures and interproximal regions. ${ }^{6}$ The effectiveness of pastes containing diamond and aluminum oxide for polishing resin materials have been indicated in studies. ${ }^{8,10}$ Using pastes can yield results very similar to the natural appearance of the teeth and increases the surface roughness. ${ }^{15}$

Increased microhardness can improve the fracture toughness and wear resistance of the restoration $^{16,17}$, and prevents the deformation under various forces. ${ }^{18}$ Filler particle size and ratio of the particles within the material affect the microhardness of a restorative material. ${ }^{12,17-19}$

There is no consensus regarding which polishing and finishing system is more effective. ${ }^{4,9,20}$ Furthermore, there are only a few studies that evaluate the correlation of surface roughness and microhardness ${ }^{21-23}$, and the existing studies have not definitively concluded whether the change in surface properties occur due to the finishing and polishing techniques and/or the characteristics of the material. ${ }^{12,22,20}$

Hence, the aim of this study was to evaluate the effects of various finishing and polishing techniques on the surface roughness and microhardness of the resin restorative materials used in pediatric dentistry.

The null hypothesis was " $\mathrm{H}_{0}$ : Various finishing and polishing techniques do not affect the surface roughness and microhardness of the resin restorative materials used in pediatric dentistry".

\section{MATERIALS AND METHODS}

Before starting the study, power analysis was performed to determine the required sample size for a maximum error of $20 \%, 5 \%$ type 1 error and 95\% power for roughness and microhardness assessments, and at least 7 discs were required. All specimens were prepared and finished by the same researcher strictly following the manufacturer's instructions to reduce variability.

A total of 168 samples were prepared according to the manufacturer's instructions using standard plexiglass molds (5-mm diameter, 2-mmthick) using three resin restorative materials. A2shade resin restorative materials were shown in Table 1. Mylar strips (SNA, Universal Strips, Germany) were placed and lightly pressed against the specimens using $1 \mathrm{~mm}$-thick glass slides on both surfaces to prevent air bubble formation and to obtain a leveled surface. 
Table 1. The resin restorative materials.

\begin{tabular}{|c|c|c|c|c|c|c|}
\hline Materials & Contents & $\begin{array}{l}\text { Type of } \\
\text { Material }\end{array}$ & $\begin{array}{l}\text { Weight/ } \\
\text { Volume of } \\
\text { Filler } \\
\text { Particles }\end{array}$ & $\begin{array}{l}\text { Particle } \\
\text { Size }\end{array}$ & Color & $\begin{array}{l}\text { Producing } \\
\text { Company }\end{array}$ \\
\hline Dyract XP & $\begin{array}{l}\text { Urethan dimethacrylate } \\
\text { (UDMA), Dimethacrylate } \\
\text { modified carboxylic acid } \\
\text { (TCB resin), camphorquinone, } \\
\text { Ethyl-4-dimethylamino } \\
\text { benzoate, butyl hydroxy } \\
\text { toluene (BHT), UV stabilizer, } \\
\text { Strontium-alumino-sodium- } \\
\text { phosphorus Silicate glass, } \\
\text { silicon dioxide, strontium } \\
\text { ureide, iron oxide and titanium } \\
\text { oxide pigments }\end{array}$ & Compomer & $\% 73 / \% 47$ & $\begin{array}{l}\text { Average: } \\
0.8 \mu \mathrm{m}\end{array}$ & $\mathrm{A} 2$ & $\begin{array}{l}\text { Dentsply/De } \\
\text { Trey Konstanz, } \\
\text { Germany }\end{array}$ \\
\hline $\begin{array}{l}\text { Bulk Fill } \\
\text { Filtek }^{\mathrm{TM}}\end{array}$ & $\begin{array}{l}\text { Bis-GMA, UDMA, 1,12- } \\
\text { dodecan-DMA, Bis-EMA, } \\
\text { Zirconia and Silica fillers }\end{array}$ & $\begin{array}{c}\text { Composite } \\
\text { Resin }\end{array}$ & $\begin{array}{c}\% 64.5 / \\
\% 42.5\end{array}$ & $\begin{array}{c}0.01- \\
4.5 \mu \mathrm{m}\end{array}$ & $\mathrm{A} 2$ & $\begin{array}{c}3 \text { M ESPE } \\
\text { GmbH Seefeld, } \\
\text { USA }\end{array}$ \\
\hline $\begin{array}{c}\text { Beautifil } \\
\text { II }\end{array}$ & $\begin{array}{l}\text { Bis-GMA (bisphenol A } \\
\text { glycidyl ether dimethacrylate), } \\
\text { TEGDMA (triethylene glycol } \\
\text { dimethyacrylate), } \\
\text { Aluminofloro borosilicate } \\
\text { glass, camphorquinone }\end{array}$ & Giomer & $\begin{array}{c}\% 83.3 / \\
\% 68.6\end{array}$ & $0.01-5 \mu \mathrm{m}$ & A2 & $\begin{array}{l}\text { Shofu Inc. } \\
\text { Kyoto, }\end{array}$ \\
\hline
\end{tabular}

The light density of the LED light-curing unit (3M ESPE Elipar S10 $1790 \mathrm{~mW} / \mathrm{cm}^{2}$ ) was measured using a radiometer (HILUX Curing Light Meter, Benlioglu; Ankara, Turkey) before each polymerization to confirm that the device had the required light intensity. After polymerization, all samples were stored in distilled water at $37{ }^{\circ} \mathrm{C}$ for 24 hours.

7 specimens from each group were allocated as controls and received no finishing and polishing technique. The finishing and polishing techniques used in the study are presented in Table 2 .

Table 2. The finishing and polishing techniques.

\begin{tabular}{rll}
\hline $\begin{array}{c}\text { Finishing and Polishing } \\
\text { Techniques }\end{array}$ & \multicolumn{1}{c}{ Composition } & \multicolumn{1}{c}{ Producing Company } \\
\hline Tungsten Carbide Burs & 12-bladed tungsten carbide bur & \multicolumn{1}{c}{ Carbide Burs, Kerr } \\
Sof-Lex® Disc & Aluminum oxide-coated abrasive discs & $\begin{array}{l}\text { 3M ESPE, St. Paul, MN, } \\
\text { USA }\end{array}$ \\
Sof-Lex Spiral Wheels & $\begin{array}{l}\text { Abrasive wheels that are impregnated with } \\
\text { aluminum oxide }\end{array}$ & $\begin{array}{l}\text { 3M ESPE, St. Paul, MN, } \\
\text { Enamel Plus Shiny }\end{array}$ \\
Shiny A & $\begin{array}{l}\text { Abrasives containing 3-micron diamond paste + } \\
\text { goat hairbrush } \\
\text { Shiny B }\end{array}$ & $\begin{array}{l}\text { Abrasives containing 1-micron diamond paste + } \\
\text { goat hairbrush } \\
\text { Shiny C }\end{array}$ \\
Aluminum oxide paste + the felt brush & Micerium S., Avegno, Italy \\
\hline
\end{tabular}

For the experimental groups, the specimens were finished using a high-speed handpiece under watercooling and tungsten carbide burs, all in the same direction parallel to the surface. Subsequently, the samples were randomly divided into groups of 7 , treated with three different polishing techniques according to the manufacturer's instructions.
Low-speed handpiece at $20000 \mathrm{rpm}$ was used for finishing and polishing procedure and each finishing and polishing material was replaced after one use.

Discs (Sof-Lex ${ }^{\circledR}$ Disc, 3M ESPE, St. Paul, MN, USA), spiral wheels (Sof-Lex Spiral Wheels) or brushes (Enamel Plus Shiny, Micerium S., Avegno, 
Italy) used for polishing were applied with the same pressure according to the manufacturer's instructions. Moreover, for standardization, all finishing and polishing agents were applied for 15 seconds, after which each sample was washed with air-water spray for 10 seconds and dried for 5 seconds.

Surface roughness was measured with a profilometer (Perthometer M2 Profilometer, Mahr, Germany). Three measurements from different sites were made for each specimen, and the average value $(\mathrm{Ra})$ was used for statistical analysis.

Vickers microhardness number (VHN) was evaluated using a microhardness tester (Zwick/Roell ZHV 10, Germany). During Vickers hardness measurement, a $200 \mathrm{~g}$ load was applied for 17 seconds. Three measurements from different sites were made for each specimen, and microhardness was calculated accordingly.
The Kolmogorov-Smirnov goodness-of-fit test was used to decide which hypothesis testing would be used for each obtained data set. Surface roughness values of the resin composite restorative materials were normally distributed; thus, the independent samples t-test was used. The one-way ANOVA (Analysis of Variance) test was used for intergroup comparison. The Kruskal-Wallis Test was used for to compare the groups in terms of microhardness $(\mathrm{p}<0.05)$. The data conformed to normal distribution was normally distributed, therefore, Pearson's correlation test was used to investigate any correlations between the different finishing and polishing techniques and the surface roughness and microhardness values of the applied resin restoratives materials $(\mathrm{p}<0.05)$.

\section{RESULTS}

The means and standard deviations of surface roughness $(\mathrm{Ra}: \mu \mathrm{m})$ are listed in Table 3.

Table 3. The means and standard deviations Surface Roughness Values of Resin Composite Restorative Materials According to Finishing and Polishing Techniques $(\mathrm{Ra}: \mu \mathrm{m})(\mathrm{mean} \pm \mathrm{SD})$

\begin{tabular}{ccccc}
\hline $\begin{array}{c}\text { Finishing and Polishing } \\
\text { Techniques }\end{array}$ & n & Dyract XP & Filtek $^{\text {TM }}$ Bulk Fill & Beautifil II \\
\hline Control Group & 7 & $0.062( \pm 0.015)^{\mathrm{Aa}}$ & $0.067( \pm 0.012)^{\mathrm{aA}}$ & $0.056( \pm 0.012)^{\mathrm{aA}}$ \\
Sof-Lex Disc & 7 & $0.279( \pm 0.167)^{\mathrm{Ba}}$ & $0.123( \pm 0.025)^{\mathrm{bB}}$ & $0.244( \pm 0.085)^{\mathrm{bAB}}$ \\
Sof-Lex Spiral Wheels & 7 & $0.210( \pm 0.072)^{\mathrm{Ba}}$ & $0.135( \pm 0.031)^{\mathrm{bB}}$ & $0.236( \pm 0.048)^{\mathrm{bA}}$ \\
Enamel Plus Shiny & 7 & $0.161( \pm 0.66)^{\mathrm{Ba}}$ & $0.131( \pm 0.032)^{\mathrm{bA}}$ & $0.193( \pm 0.045)^{\mathrm{bA}}$ \\
\hline
\end{tabular}

$\mathrm{p}<0.05$

Different lower-case letters in the same column indicate a significant difference.

Different upper-case letters in the same row indicate a significant difference.

The surface roughness obtained after using Sof-Lex Disc was significantly higher for Dyract XP compared to Filtek ${ }^{\mathrm{TM}}$ Bulk Fill $(\mathrm{p}<0.05)$. In the Sof-Lex Disc group, surface roughness result of Beautifil II was not significantly different than the remaining two materials. The surface roughness obtained after using Sof-Lex Spiral Wheels was significantly lower for Filtek ${ }^{\mathrm{TM}}$ Bulk Fill than the remaining two materials $(p<0.05)$. It was determined that the control and Enamel Plus Shiny group displayed the lowest surface roughness values on the restorative materials used in this study and there was no statistically difference between the two.
Microhardness values of the resin restorative materials according to the used finishing and polishing techniques are presented in Table 4. 
Gül Aydın E, et al.

Table 4. The Microhardness Values of the Resin Restorative Materials According to the Finishing and Polishing Methods (VHN) (Mean \pm SD).

\begin{tabular}{ccccc}
\hline Finishing and Polishing Techniques & $\mathbf{n}$ & Dyract XP & Filtek ${ }^{\mathrm{TM}}$ Bulk Fill & Beautifil II \\
\hline Control Group & 7 & $84.2^{\mathrm{aA}}( \pm 2.041)$ & $92.1^{\mathrm{aB}}( \pm 0.187)$ & $97.4^{\mathrm{aB}}( \pm 5.521)$ \\
Sof-Lex Disc & 7 & $126.7^{\mathrm{bA}}( \pm 4.036)$ & $137.4^{\mathrm{bA}}( \pm 11.024)$ & $188.1^{\mathrm{bB}}( \pm 16.448)$ \\
Sof-Lex Spiral Wheels & 7 & $147.5^{\mathrm{cA}}( \pm 3.155)$ & $138.7^{\mathrm{bB}}( \pm 4.091)$ & $173.2^{\mathrm{cC}}( \pm 14.790)$ \\
Enamel Plus Shiny & 7 & $143.5^{\mathrm{cA}}( \pm 7.939)$ & $104.8^{\mathrm{cB}}( \pm 7.904)$ & $203.3^{\mathrm{bC}}( \pm 3.987)$ \\
\hline
\end{tabular}

$\mathrm{p}<0.05$

Different lower-case letters in the same column indicate a significant difference.

Different upper-case letters in the same row indicate a significant difference.

In the control group, the microhardness value of Dyract XP was significantly lower compared to Filtek $^{\mathrm{TM}}$ Bulk Fill and Beautifil II $(\mathrm{p}<0.05)$. In the Sof-Lex Disc group, the microhardness value of Beautifil II was significantly higher compared to the remaining two materials $(p<0.05)$. In the SofLex Spiral and Enamel Plus Shiny groups, the resulting microhardness values of the different resin restorative materials were significantly different $(\mathrm{p}<0.05)$ and were in the following order: Beautifil II $>$ Dyract XP> Filtek ${ }^{\mathrm{TM}}$ Bulk Fill.

Correlation analysis results of surface roughness and microhardness values are presented in Figure 1.

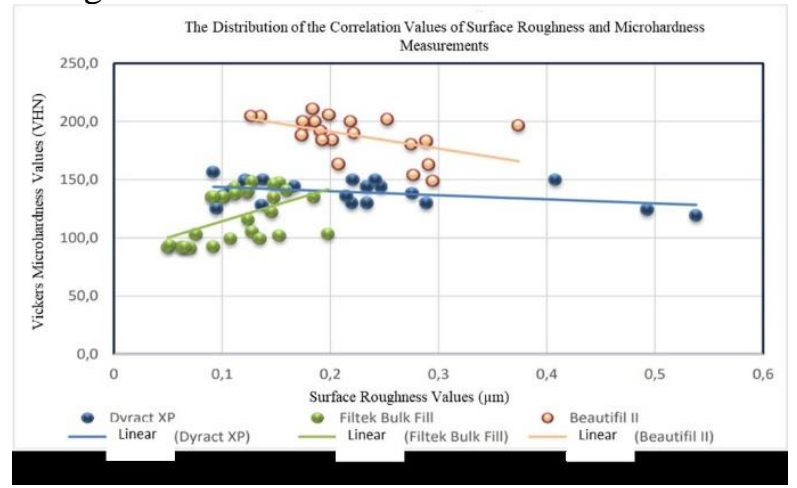

Figure 1. The distribution of correlation values between the surface roughness and microhardness values of the resin restorative materials according to the finishing and polishing techniques.

Surface roughness and microhardness values were positively correlated for Filtek ${ }^{\mathrm{TM}}$ Bulk Fill and negatively correlated for Dyract XP and Beautifil II.

\section{DISCUSSION}

In clinical practice, the finishing of resin restorative materials under a Mylar strip results in the lowest surface roughness. ${ }^{2,4,8,12-14,22,24}$ The initial surface obtained by using a Mylar strip is an unstable and resin free surface, rich in organic matrix and monomers. ${ }^{2,9}$ Therefore, this layer should be removed through finishing and polishing procedure. ${ }^{14,20,22,25,26}$

In our study, the control group had the smoothest surface and significantly lower surface roughness compared to the Sof-Lex Disc and SofLex Spiral Wheels groups $(p<0.05)$. However, the control and Enamel Plus Shiny groups were not statistically significantly different. For dental materials, surface roughness below $0,2 \mu \mathrm{m}$ significantly reduced the possibility of bacterial adhesion. ${ }^{27}$ Thus, it is recommended that the $\mathrm{Ra}$ values should be lower than $0.2 \mu \mathrm{m}$ to prevent bacteria accumulation in the mouth. ${ }^{2,27,28}$ It should be noted that surface roughness in the Enamel Plus Shiny group was below the indicated threshold.

In the Sof-Lex Disc and Sof-Lex Spiral Wheels groups, the surface roughness of Dyract XP was significantly higher (Ra: $0.279 \mu \mathrm{m}, 0.210 \mu \mathrm{m}$ ) compared to Filtek ${ }^{\mathrm{TM}}$ Bulk Fill (Ra: $0.123 \mu \mathrm{m}$, $0.135 \mu \mathrm{m})$. Ryba et al. ${ }^{29}$ indicated that resins with larger particles result in rougher surfaces after finishing and polishing. When the ratio of the organic matrix is smaller than filler particles, it is easier for the particles to come loose. Hence, resins with smaller particles are easier to polish. ${ }^{30}$ Considering the particle sizes of Dyract XP (0.8 $\mu \mathrm{m})$ and Filtek ${ }^{\mathrm{TM}}$ Bulk Fill (0.01- $\left.4.5 \mu \mathrm{m}\right)$, our results are consistent with the notion that surface roughness is associated with the size of filler particles.

In the Sof-Lex Disc group, surface roughness was statistically different between Filtek ${ }^{\mathrm{TM}}$ Bulk Fill and Dyract XP. However, surface roughness was not statistically different between Beautifil II and the other two materials. This finding could be 
ascribed to the shape and abrasive properties of the finishing and polishing techniques and the size of the filler particles of the restorative materials.

Sof-Lex Spiral Wheels used with Filtek ${ }^{\mathrm{TM}}$ Bulk Fill had a statistically significantly smoother $(p<0.05)$ surface compared to the other techniques. The content and size of the filler particles of the resin restorative materials play an important role in the success of the finishing/polishing and longevity of the restoration. ${ }^{31}$

The evaluation of the effectiveness of the finishing/polishing techniques require the definition of the surface roughness, and determining the microhardness values using surface hardness tests, which is one of the most important factors that determine the clinical application and success of the material ${ }^{2,5,18-19,21} \mathrm{It}$ is also reported that when resin composite materials are polymerized using a transparent band under pressure, the ratio of particles decreases and the ratio of the resin increases on the surface, thus reducing microhardness. ${ }^{21}$ Therefore, finishing and polishing techniques are critical and should be applied to improve the chemical stability of the material, the mechanical surface properties, and to remove the resin-rich surface layer. ${ }^{20,21,24}$

Every restorative material has a different microhardness value as the chemical composition and filler content affect physical properties. ${ }^{2,13,17,18}$ The materials with higher filler content have higher microhardness values. ${ }^{17-19}$ The filler weight ratios of the used restorative materials were as follows: $83.3 \%$ for Beautifil II, $73 \%$ for Dyract XP, and $64,5 \%$ for Filtek ${ }^{\mathrm{TM}}$ Bulk Fill. $^{32,33}$

In the control group, the microhardness of Dyract XP (84.2 VHN) was significantly lower $(p<0.05)$ than Filtek ${ }^{\mathrm{TM}}$ Bulk Fill $(92.1 \mathrm{VHN})$ and Beautifil II (97.4 VHN). We ascribe this result to the differences in the polymer matrix, rather than particle content and amount.

In the Sof-Lex Disc group, the microhardness of Beautifil II (188.1 VHN) was significantly higher than the other two materials $(p<0.05)$. We ascribe this difference to the relatively higher filler content of the Beautifil II. Indeed, the literature indicates that microhardness is positively correlated with the filler content of the material. ${ }^{17,34}$
In the Sof-Lex Spiral group, the microhardness of the three resin restorative materials were significantly different and in the following order: Beautifil II > Dyract XP> Filtek ${ }^{\mathrm{TM}}$ Bulk Fill. This result could be explained by the filler content of the materials. The literature indicates that resin composite materials with a higher filler content have higher hardness values compared to the resin materials without fillers. ${ }^{4}$

In the Enamel Plus Shiny group, the microhardness of the three resin restorative materials were significantly different and in the following order: Beautifil II> Dyract XP> Filtek ${ }^{\mathrm{TM}}$. Enamel Plus Shiny contains aluminum oxide particles together with diamond particles as abrasives. The filler content of the Filtek ${ }^{\mathrm{TM}}$ Bulk Fill is lower than the other two materials, and the diamond particles are more abrasive than aluminum oxide particles. Consequently, more filler particles were removed from the surface of the Filtek ${ }^{\mathrm{TM}}$ Bulk Fill, and thus surface microhardness was lower.

There are heterogeneous components that influence the surface roughness and microhardness values of resin composite materials. ${ }^{17,19}$ However, it is accepted that finishing/polishing techniques are effective in improving surface hardness. ${ }^{5,21}$

The in vitro studies have concluded that surface roughness and microhardness properties of restorative materials were correlated..$^{21-23}$ Tjan and Chan. ${ }^{23}$ indicated that there was a direct correlation between surface roughness and microhardness and that the highest surface roughness values were found together with the highest microhardness values. Erdemir et al. ${ }^{22}$ reported that the high surface roughness values were associated with high microhardness values in tooth-colored restorative materials.

The microhardness evaluation should be done on a smooth surface. ${ }^{21}$ Even though we found that the surfaces that were finished with the Mylar Strip (i.e. the control group) had the smoothest surfaces, this layer must be removed since due to poor surface properties and higher organic content.

According to the results of the present study, there was a positive correlation between the surface roughness and the microhardness values of Filtek $^{\mathrm{TM}}$ Bulk Fill after finishing and polishing. In 
contrast, this correlation was negative for Dyract $\mathrm{XP}$ and Beautifil II. Our results are consistent with the literature. ${ }^{20-21}$

The positive correlation determined for Filtek ${ }^{\mathrm{TM}}$ Bulk Fill indicates that the final obtained surface is smoother due to the smaller size of the filler particles within the material and that the microhardness values are lower because the filling content is lower.

The purpose of finishing and polishing is to obtain a more resistant and stable surface from the resin materials. However, this is not always possible due to the resin composite materials' different filler particles, particle sizes, and different hardness values associated with filler particles and the matrix, as was observed in the present study.

\section{CONCLUSIONS}

Our null hypothesis " $\mathrm{H}_{0}$ " was rejected as all resin restorative materials yielded different results for different finishing and polishing techniques due to their specific physical and mechanical properties. In this context, it is not possible to say that a finishing and polishing technique that yields the best surface properties for a specific material may do so when applied to a different material. It seems that the ideal finishing and polishing techniques should be chosen according to the properties of resin restorative materials. Bulk fill composite resins eliminate incremental technique and reduce chair time in children, and when used with Enamel Plus Shiny, the resulting smooth surface properties will be useful in terms of pediatric dentistry in the clinical setting.

\section{ACKNOWLEDGMENTS}

This research was supported by Ankara University Scientific Research Coordination Unit (Project number 15H0234005)

\section{CONFLICTS OF INTEREST}

The authors declare no conflicts of interest.

\section{Hangi Bitirme Ve Parlatma Tekniği Yüzey}

\section{Pürüzlülü̈̆̈̈ Ve Mikrosertlik Iç̧in Daha Efektiftir?}

\section{$\ddot{O} Z$}

Amaç: Bitirme ve parlatma $(F / P)$ tekniklerinin kompozit rezin restorasyon materyallerinin yüzey pürüzlülüğ̈ ve mikro sertliği üzerindeki etkilerini değerlendirilerek materyal için en ideal yüzey özelliği oluşturan bitirme ve parlatma tekniğinin araştırılmasıdır. Gereç ve Yöntemler: Pleksiglas kalıplar kullanılarak 168 örnek hazırlamak için kompomer, kompozit rezin ve giomer kullanıld v ve örnekler F/P tekniklerine tabi tutuldu. Kontrol Grubunda F/P yapılmadı. F/P için; Sof-Lex Disk; Sof-LexTM Spiral Lastikler ve Enamel Plus Shiny kullanıld. Yüzey pürüzlülüğü ve mikro sertlik değerleri ölçüldü. Veriler tek yönlü ANOVA, iki bağımsız örnek ttesti, Kruskal Wallis kullanılarak analiz edildi ve iki parametre arasindaki korelasyon için Pearson korelasyon testi kullanıldı $(p<0,05)$. Bulgular: Elde edilen veriler doğrultusunda yüzey pürüzlülük değerler karşılaştırıldı̆̆ında; Enamel Plus Shiny ile kontrol grubu arasında istatistiksel olarak anlaml fark bulgulanmadı. Sof-Lex Disk kullanıldığında Dyract XP grubunda, yüzey pürüzlülüğ̈̈nün anlamlı derecede daha yüksek olduğu tespit edildi ( $p<0,05)$. Sof-Lex Spiral Lastikler kullanıldı̆̆ında, FiltekTM Bulk Fill'in istatistiksel olarak anlamlı derecede daha düşük yüzey pürüzlülüğ̈̈ değeri gösterdiği bulgulandı ( $p<0,05)$. Mikrosertlik değerlerinde ise Sof-Lex Disk kullanıldı̆̆ında; Beautifil II ye ait mikrosertlik değerlerinin anlaml olarak daha yüksek olduğu tespit edildi ( $p<0,05)$, kontrol grubu için ise Dyract XP'nin, FiltekTM Bulk Fill ve Beautifil II ile karşılaştırıldı̆̆ında mikrosertlik değerinin en düşük değer gösterdiği bulgulandl. Sof-Lex Spiral Lastikler ve Enamel Plus Shiny için, restoratif materyallerin mikrosertlik değerleri arasında istatistiksel olarak anlaml farklılıklar gözlenmiştir. Yüzey pürüzlülüğ̈̈ ve mikro sertlik arasindaki korelasyon ise; FiltekTM Bulk Fill materyalinde pozitif korelasyona sahipken; Dyract XP ve Beautifil II materyallerinde negatif korelasyona sahiptir. Sonuçlar: Uygun F/P prosedürleri, restoratif materyaller için estetik ve uzun ömürlülüğ̈̈ arttıran gerekli adımlardır. Çalışmamızın sınırları dahilinde, en ideal bitirme ve parlatma tekniğinin kullanılan rezin içerikli restoratif materyalin özelliklerine bağll olarak değişkenlik gösterdiği, F/P tekniklerinin etkilerinin hem bitirme ve parlatma tekniğine hem de restoratif materyale bağlı olduğu sonucuna varılmıştır. Anahtar

Kelimeler: Diş parlatma, dental materyaller, bitirme ve parlatma materyalleri.

\section{REFERENCES}

1. Dutra D, Pereira G, Kantorski KZ, Valandro LF, Zanatta FB. Does Finishing and Polishing of Restorative Materials Affect Bacterial Adhesion and Biofilm Formation? A Systematic Review. Oper Dent. 2018;43: E37-E52. 
2. Eden E, Cogulu D, Attın T. The Effect of Finishing and Polishing Systems on Surface Roughness, Microhardness and Microleakage of a Nanohybrid Composite. Journal of International Dental and Medical Research 2012; 5: 155-160.

3. Hosoya Y, Shiraishi T, Odatsu T, Nagafuji J, Kotaku M, Miyazaki M. Powers Jm Effects of polishing on surface roughness, gloss, and color of resin composites. Int J Oral Sci 2011; 53: 283-291.

4. Mandikos MN, McGivney GP, Davis E, Bush PJ, Carter JM. A comparison of the wear resistance and hardness of indirect composite resins. J Prosthet Dent 2001; 85: 386-395.

5. Yap AUJ, Sau CW, Lye KW. Effects of finishing/polishing time on surface characteristics of tooth-coloured restoratives. J Oral Rehabil 1998; 25: 456-461.

6. Jefferies SR. Abrasive finishing and polishing in restorative dentistry: a state-of-the-art review. Dent Clin North Am 2007; 51: 379-397.

7. Mallya PL, Acharya S, Ballal V, Ginjupallı K, Kundabala M, Thomas M. Profilometric study to compare the effectiveness of various finishing and polishing techniques on different restorative glass ionomer cements. Journal of Interdisciplinary Dentistry 2013;3:86-90.

8. Gedik R, Hürmüzlü F, Coşkun $A$, Bektaş $O O$, Ozdemir AK. Surface roughness of new microhybrid resin-based composites. J Am Dent Assoc 2005;136: 1106-1112.

9. Antonson SA, Yazıcı AR, Kılınç E, Antonson DE, Hardigan PC. Comparison of different finishing/ polishing systems on surface roughness and gloss of resin composites. J Dent 2011;39:9-17.

10. Lesage B. Finishing and polishing criteria for minimally invasive composite restorations. General Dentistry 2010;59:422-428.

11. Ishii R, Takamizawa T, Tsujimoto A, Suzuki S, Imai A, Barkmeier WW, Latta MA, Miyazaki M. Effects of Finishing and Polishing Methods on the Surface Roughness and Surface Free Energy of Bulk-fill Resin Composites. Oper Dent. 2020;45:91-104.

12. Baseren M. Surface roughness of nanofill and nanohybrid composite resin and ormocer-based toothcolored restorative materials after several finishing and polishing procedures. J Biomater Appl 2004;19:121134.

13. Türkün LS, Türkün $M$. The effect of one-step polishing system on the surface roughness of three esthetic resin composite materials. Oper Dent 2004;29: 203-211.

14. Kemaloglu H, Karacolak G, Turkun LS. Can Reduced-Step Polishers Be as Effective as MultipleStep Polishers in Enhancing Surface Smoothness? J Esthet Restor Dent 2017;29.1:31-40.

15. Ferraris F. Adhesion, layering, and finishing of resin composite restorations for class II cavity preparations. Eur J Esthet Dent 2007;2:210-221.

16. William JA. Wear and wear particles-some fundamentals. Tribiology International 2005; 38:863870.

17. Kim KH, Ong JL, Okuno O. The effect of filler loading and morphology on the mechanical properties of contemporary composites. J Prosthet Dent 2002;87: 642-649.

18. Manhart J, Kunzelmann KH, Chen HY, Hickel R. Mechanical properties of new composite restorative materials. J Biomed Mater Res 2000;53:353-361.

19. Scougall-Vilchis RJ, Hotta Y, Hotta M, Idono T, Yamamoto K. Examination of composite resins with electron microscopy, microhardness tester and energy dispersive X-ray microanalyzer. Dent Mater J 2009;28: 102-112.

20. Schmitt VL, Puppin-Rontani RM, Naufel FS, Ludwig D, Ueda JK, Sobrinho LC. Effect of finishing and polishing techniques on the surface roughness of a nanoparticle composite resin. Braz J Oral Sci 2011; 10: 105-108.

21. Munchow EA, Correa MB, Ogliari FA, Piva E, Zanchi $\mathrm{CH}$. Correlation between surface roughness and microhardness of experimental composites with varying filler concentration. J Contemp Dent Pract 2012; 13:299-304.

22. Erdemir U, Yıldız E, Eren MM, Ozsoy A, Topcu FT. Effects of polishing systems on the surface roughness of tooth-colored materials. J Dent Sci 2013; 8: 160-169.

23. Tjan AH, Chan CA. The polishability of posterior composites. J Prosthet Dent 1989; 61: 138-146.

24. Daud A, Gray G, Lynch CD, Wilson NHF, Blum IR. A randomised controlled study on the use of finishing and polishing systems on different resin composites using 3D contact optical profilometry and scanning electron microscopy. J Dent. 2018; 71:25-30.

25. Özgünaltay G, Yazici AR, Görücü J. Effect of finishing and polishing procedures on the surface roughness of new tooth-coloured restoratives. J Oral 
Rehabil 2003, 30:218-224.

26. Krejci I, Lutz F, Borett1 R. Resin composite polishing-filling the gaps. Quintessence Int 1999; 30: 490-495.

27. Bollen CM, Lambrechts P, Quirynen M. Comparison of surface roughness of oral hard materials to the threshold surface roughness for bacterial plaque retention: a review of the literature. Dent Mater 1997; 13: 258-269.

28. Hamouda IM. Effects of Various Beverages on Hardness, Roughness, and Solubility of Esthetic Restorative Materials. J Esthet Restor Dent 2011; 23: 315-322.

29. Ryba TM, Dunn WJ, Murchison DF. Surface roughness of various packable composites. Oper Dent 2002; 27:243-247.

30. Yap AUJ, Mok BYY. Surface finish of a new hybrid aesthetic restorative material. Oper Dent 2002; 27: 161166.

31. Senawongse P, Pongprueksa P. Surface roughness of nanofill and nanohybrid resin composites after polishing and brushing. J Esthet Restor Dent 2007; 19: 265-273.

32. Lien W, Vandewalle KS. Physical properties of a new silorane-based restorative system. Dent Mater., 2010; 26: 337-344.

33. Orlowskı M, Tarczydło B, Chałas R. Evaluation of Marginal Integrity of Four Bulk-Fill Dental Composite Materials: In Vitro Study. The Scientific World Journal 2015; 701262.

34. Ehrmann E, Medioni E, Brulat-Bouchard N. Finishing and polishing effects of multiblade burs on the surface texture of 5 resin composites: microhardness and roughness testing. Restor Dent Endod., 2018;26: 1-12. 